\title{
Depth diversity profile of polychaete worms in Bahía Chatham, Isla del Coco National Park, Costa Rican Pacific
}

\author{
Jeffrey A. Sibaja-Cordero ${ }^{1,2,3}$, Jorge Cortés ${ }^{1,2}$ \& Harlan K. Dean ${ }^{4}$ \\ 1. Centro de Investigación en Ciencias del Mar y Limnología (CIMAR), Universidad de Costa Rica, San Pedro, 11501- \\ 2060 San José, Costa Rica; jeffro@costarricense.cr \\ 2. Escuela de Biología, Universidad de Costa Rica, San Pedro, 11501-2060 San José, Costa Rica \\ 3. Departamento de Ecología y Biología Animal, Facultad de Ciencias del Mar, Universidad de Vigo, Campus Lagoas \\ Marcosende, Vigo, España. \\ 4. Department of Invertebrates, Museum of Comparative Zoology, Harvard University, 26 Oxford St., Cambridge, \\ Massachusetts 02138, USA
}

Received 17-II-2012. Corrected 28-VI-2012. Accepted 24-IX-2012.

\begin{abstract}
The subtidal benthos of tropical islands has been poorly studied in the Eastern Tropical Pacific. Several studies have been published on taxonomic collections from oceanic islands in the region, but ecological features and community structure are practically unknown. In the present study, composition of the polychaete community along a depth gradient from the sand bottom of Bahía Chatham, Isla del Coco National Park, Costa Rica is analyzed. Fifty species of polychaetes belonging to 28 families were found. There is a peak in diversity, abundance and richness at $28-30 \mathrm{~m}$. The lowest values occurred at $50 \mathrm{~m}$ depth with values increasing below this depth. The composition of species changed with depth with some species being found only at depths either less than or greater than $50 \mathrm{~m}$. This pattern can be explained in part by the location of the thermocline that occurred at around 50m depth. Citation: Sibaja-Cordero, J.A., J. Cortés \& H.K. Dean. 2012. Depth diversity profile of polychates worms in Bahía Chatham, Isla del Coco National Park, Pacific of Costa Rica. Rev. Biol. Trop. 60 (Suppl. 3): 293-301. Epub 2012 Dec 01.
\end{abstract}

Key words: Diversity, Polychaeta, composition, oceanic islands, infaunal, tropical benthos, Isla del Coco, Costa Rica.

Few ecological studies of polychaetes have been conducted in soft-bottom sites in the Eastern Tropical Pacific. Most of the studies published are taxonomic description and catalogues of tropical regions, for example the Galápagos (Treadwell 1928, Berkeley \& Berkeley 1939, Westheide 1974), Central America (Chamberlin 1919, Hartman 1959, Dean 2009), Coiba (Aguado \& San-Martín 2006), the coast of Panamá (Monro 1928, Fauchald 1977), and Mexico (Berkeley \& Berkeley 1939, de León-González et al. 2009). The ecology of polychaetes is poorly known in subtidal habitats of the tropics (Alongi 1990) with the most recent works conducted in Mexico (HernándezAlcántara \& Solís-Weiss 2011).
Ecological studies of soft bottom communities in Costa Rican waters show that polychaete biodiversity changes with depth and sediment type. These studies were carried out in estuarine or anoxic basin systems (NicholsDriscoll 1976, Maurer \& Vargas 1984, Dean 1996 a, b, León-Morales \& Vargas 1998). In these studies abundance decreased in Golfo Dulce with depth, and identity and abundance of polychaetes changed in the inner and shallow part of the Gulf of Nicoya. Others studies were carried out in intertidal mud flats (Vargas 1987, 1988), and sand beaches (Dexter 1974)..

The ecology of soft-bottom communities has never been studied in Isla del Coco National Park (also known as Cocos Island), and the 
patterns of their distribution are unknown. Only nine species of polychetes have been reported (Dean 2009), but recent research has increased the number to 113 species (Dean et al. 2012). This new list of species is the product of a series of expeditions carried out by scientists from CIMAR, with the objective of studying the biodiversity of the island's different habitats (coral reefs, rodolith beds, rock, gravel and sand bottoms). Fifty-five percent of those species were collected from rocky bottoms. During two expeditions bottom samples were collected in Bahía Chatham, and the depth distribution of the polychaetes was determined and presented here as an initial survey of the soft bottom communities of Isla del Coco National Park.

\section{MATERIAL AND METHODS}

We sampled Bahía Chatham (5'33'04'N, 8702'36”'W), Isla del Coco National Park, Costa Rica during the expeditions of the MV Phoenix I (9-20 October 2007) and the MY Adventure (2-13 April 2008).

A total of 14 Petite Ponar grab samples (sampling area: $152 \times 152 \mathrm{~mm}$ ) were collected in the subtidal sandy bottom of Bahía Chatham, along a depth gradient of 5-76m. The samples were collected in a transept from the shore to offshore in the mid of bay. The bathymetry of Bahía Chatham can be seen in Lizano (2001). All sediment samples were preserved in 5\% formaldehyde in seawater and stained with Rose Bengal. The samples were sieved through a $500 \mu$ mesh, gently cleaned with fresh water and transferred to a white enamel sorting tray (Vargas 1987); the organisms were identified to the lowest possible taxonomic grouping. The taxa indeterminate (indet.) a specific level represents each one different species and their identity was conserved in the statistical analysis. In this paper we present the results on polychaete fauna obtained from these samples. Some of these species have been deposited in the Zoology Museum, Universidad de Costa Rica, San Pedro, Costa Rica (Dean et al. 2012).
The total number of species, families and individuals were compared between stations defined by depth using the Chi-squared test. Species diversity (H') per station using the Shannon-Wiener function ( $(n)$ and equitability (J') were also calculated. A Cluster Analysis between stations (normal mode) and species (inverse mode) were used to represent the similarities according to the species composition data based in the Bray-Curtis distance by the single linkage method (Quinn \& Keough 2003). Moreover, a non-metric Multidimensional Scaling analysis based on Bray-Curtis similarities among stations was graphically represented. Multivariate analysis were carried out using the transformed abundances (log $\mathrm{x}+1$ ) in the free software PAST (Hammer et al. 2001).

To detect whether there is changes in the identity of species with depth a seriation test was carried out. The presence-absence data were tested using a $\mathrm{Z}$ test by Monte Carlo procedure ( 30 random matrix), with a criterion of seriation with values between 0 (no change) to 1 (total change) (Hammer et al. 2001).

\section{RESULTS}

A total of 50 species of polychaetes in 28 families were found in the studied sandy sediments (Table 1). The Family Syllidae was the most abundant with 233 individuals (representing $28.8 \%$ of the total) belonging to seven species. The species Westheidesyllis heterocirrata (Hartmann-Schröder, 1959) was the most abundant with 163 individuals (Table 1). The Family Spionidae was the second most abundant with five species and 118 individuals (14.6\%). The Family Magelonidae, with 127 individuals belonging to a single species, Magelona californica Hartman, 1944, represented 15.7\% of the total abundance (Table 1). Other families presented in appreciable numbers included the Chaetopteridae and Hesionidae (both with $\sim 60$ individuals), the Capitellidae, Pisionidae and Sabellidae. Remaining families showed abundances less than 30 individuals and were represented by one or two species. 
TABLE 1

Polychaete families, species and abundance (\%) in 14 Petite Ponar grab samples from sediments of Bahía Chatham, Isla del Coco National Park, Pacific Costa Rica. Total No. individuals $=809$

\begin{tabular}{|c|c|c|}
\hline Family & Species & $\%$ \\
\hline Acoetidae & Polyodontes panamensis (Chamberlin, 1919) & 0.12 \\
\hline Ampharetidae & Ampharetidae indet. & 0.12 \\
\hline Amphinomidae & Linopherus canariensis Langerhans, 1881 & 0.25 \\
\hline Capitellidae & Notomastus lineatus Claparéde 1870 & 5.81 \\
\hline Chaetopteridae & Mesochaetopterus alipes Monro, 1933 & 7.66 \\
\hline Dorvilleidae & Dorvillea (Dorvillea) cerasina (Ehlers, 1901) & 0.25 \\
\hline \multirow[t]{2}{*}{ Eunicidae } & Eunice biannulata Moore, 1904 & 0.12 \\
\hline & Nematonereis unicornis (Grube, 1840) & 0.12 \\
\hline \multirow{2}{*}{ Glyceridae } & Glycera brevicirris Grube 1870 & 0.37 \\
\hline & Hemipodia pustatula (Friedrich 1956) & 1.73 \\
\hline \multirow[t]{2}{*}{ Hesionidae } & Podarkeopsis brevipalpa Hartmann-Schröder, 1959 & 2.35 \\
\hline & Psamathe ancuda (Wesenberg-Lund, 1962) & 5.56 \\
\hline Lumbrineridae & Lumbrineris annulata Hartmann-Schröder, 1960 & 0.62 \\
\hline Magelonidae & Magelona californica Hartman 1944 & 15.70 \\
\hline Maldanidae & Maldanidae indet. & 0.12 \\
\hline \multirow[t]{2}{*}{ Nereididae } & Laeonereis brunnea Hartmann-Schröder, 1959 & 0.12 \\
\hline & Nereis eugeniae (Kinberg, 1866) & 0.74 \\
\hline Oenonidae & Drilonereis longa Webster, 1879 & 0.12 \\
\hline Onuphidae & Mooreonuphis elsiae de León-González, 1994 & 0.74 \\
\hline Orbiniidae & Naineris setosa (Verrill, 1900) & 0.12 \\
\hline Paraonidae & Aricidea (Aricidea) rosea Reish, 1968 & 0.12 \\
\hline \multirow[t]{2}{*}{ Phyllodocidae } & Phyllodoce madeirensis Langerhans 1880 & 0.62 \\
\hline & Phyllodoce medipapillata Moore, 1909 & 0.12 \\
\hline Pilargidae & Synelmis gorgonensis (Monro, 1933) & 1.24 \\
\hline Pisionidae & Pisione cf. galapagoensis Westheide 1974 & 4.45 \\
\hline \multirow[t]{4}{*}{ Polynoidae } & Harmothoe imbricata (Linnaeus, 1767) & 0.12 \\
\hline & Harmothoe sp. & 0.12 \\
\hline & Lepidasthenia gigas (Johnson, 1897) & 0.49 \\
\hline & Lepidasthenia ornata Treadwell, 1937 & 0.49 \\
\hline Protodrilidae & Protodrilus infundibuliformis Schmidt \& Westheide, 1977 & 0.62 \\
\hline \multirow[t]{2}{*}{ Sabellidae } & Bispira melanostigma Schmarda, 1861 & 0.25 \\
\hline & Branchiomma costaricensis Tovar-Hernández and Dean, 2010 & 3.71 \\
\hline \multirow[t]{2}{*}{ Sigalionidae } & Sigalion lewisii Berkeley \& Berkeley, 1939 & 0.12 \\
\hline & Sthenelais fusca Johnson, 1897 & 0.25 \\
\hline \multirow[t]{6}{*}{ Spionidae } & Aonides cf. glandulosa Blake, 1996 & 1.48 \\
\hline & Aonides paucibranchiata Southern, 1914 & 1.85 \\
\hline & Laonice cirrata (Sars, 1851) & 0.99 \\
\hline & Prionospio (Prionospio) sp. Day, 1961 & 10.01 \\
\hline & Spionidae indet. & 0.12 \\
\hline & Spiophanes berkeleyorum Pettibone, 1962 & 0.12 \\
\hline \multirow[t]{7}{*}{ Syllidae } & Exogone (Exogone) breviantennata Hartmann-Schröder, 1959 & 4.33 \\
\hline & Opisthodonta sp. & 0.12 \\
\hline & Paraehlersia articulata (Kudenov and Harris 1995) & 0.12 \\
\hline & Syllidae indet. & 0.25 \\
\hline & Syllis cf hyalina Grube, 1863 & 3.71 \\
\hline & Syllis garciai (Campoy, 1982) & 0.12 \\
\hline & Westheidesyllis heterocirrata (Hartmann-Schröder, 1959) & 20.15 \\
\hline \multirow[t]{2}{*}{ Terebellidae } & Polycirrus mexicanus Rioja 1947 & 0.12 \\
\hline & Polycirrus sp. & 0.25 \\
\hline Trichobranchidae & Trichobranchus hancocki (Hartman, 1955) & 0.74 \\
\hline
\end{tabular}


The highest abundance, number of families, species, and diversity (Fig. 1) reached a maximum at $28-30 \mathrm{~m}$, decreased at depths below $28 \mathrm{~m}$ and showed lowest values at $50 \mathrm{~m}$ depth, with values increasing below this depth (Abundance $=\chi^{2}: 749.78, \mathrm{p}<0.001$; Number of families $=\chi^{2}: 33.33$, p: 0.002 , Number of species $\left.=\chi^{2}: 57.80, \mathrm{p}<0.001\right)$. The equitability always takes high values, but deceased little in some stations as 30, 42, 45 and 55. Also station 5 and 51 were the lower in the island (Fig. 1).

The Cluster Analysis (Fig. 2) and nMDS ordination (Fig. 3) indicated that "deep-water stations" (below 50m) were less similar to each other than those at "shallow water stations" $(5-45 \mathrm{~m})$. Both analyses indicated that the station at $5 \mathrm{~m}$ depth is different from the other samples. In this station only Aonides paucibranchiata Southern, 1914 was found.
Station 51 only presented the glycerid Hemipodia pustatula (Friedrich, 1956). Based upon cluster analysis several groups of species were identified. These groups represented species of either "shallow or deep water stations" (Fig. 2). Multivariate analysis confirmed a change in composition of the polychaete community from "shallow to deep-water stations".

The main group of species in "shallowwater stations" presented more suspension or surface deposit-feeders. In "deep-waters stations" carnivores or omnivores dominated; only three species corresponded to surface deposit feeders and one, Polycirrus mexicanus Rioja, 1947, is a suspension feeder.

The seriation test indicated a significant change in identity of taxa along the depth gradient (Criterion $=0.61, \mathrm{z}=-3.2, \mathrm{p}=0.001$ ). In "shallow-water stations" $(5-45 \mathrm{~m}) 21$ species were
A

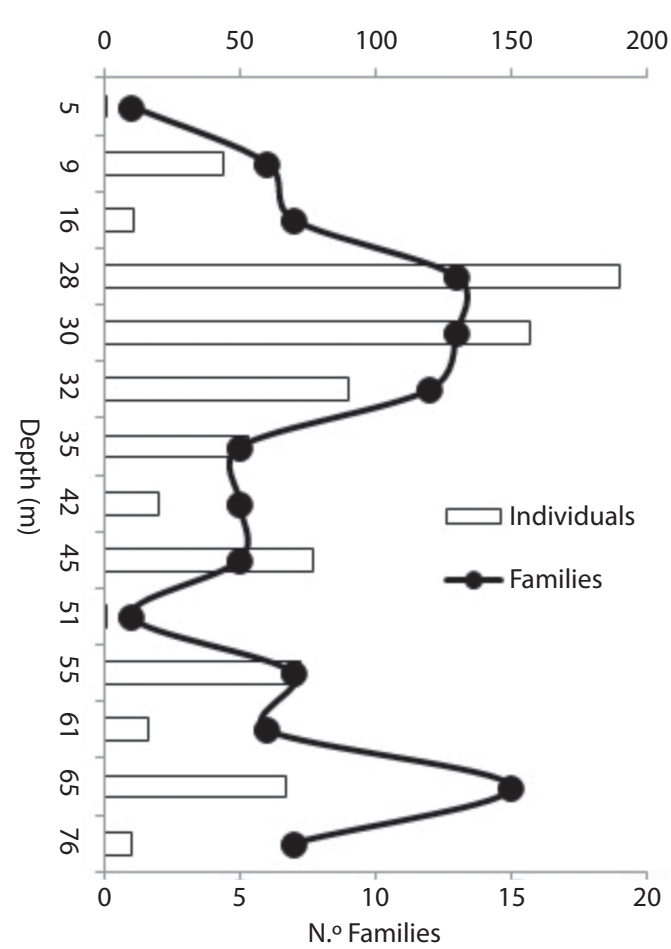

B N. ${ }^{\circ}$ Species

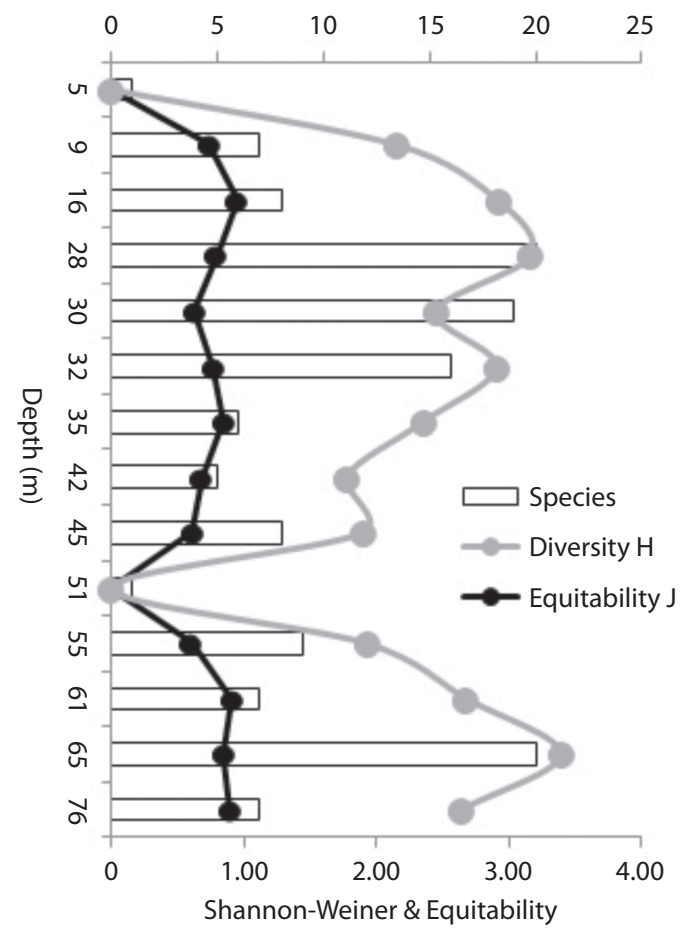

Fig. 1. Depth profiles for A) abundance of polychaete families and species and B) number of species, diversity (ShannonWiener), and equitability of the polychaete assemblage according to depth from the sandy sediments of Bahia Chatham, Isla del Coco National Park, Pacific of Costa Rica. 


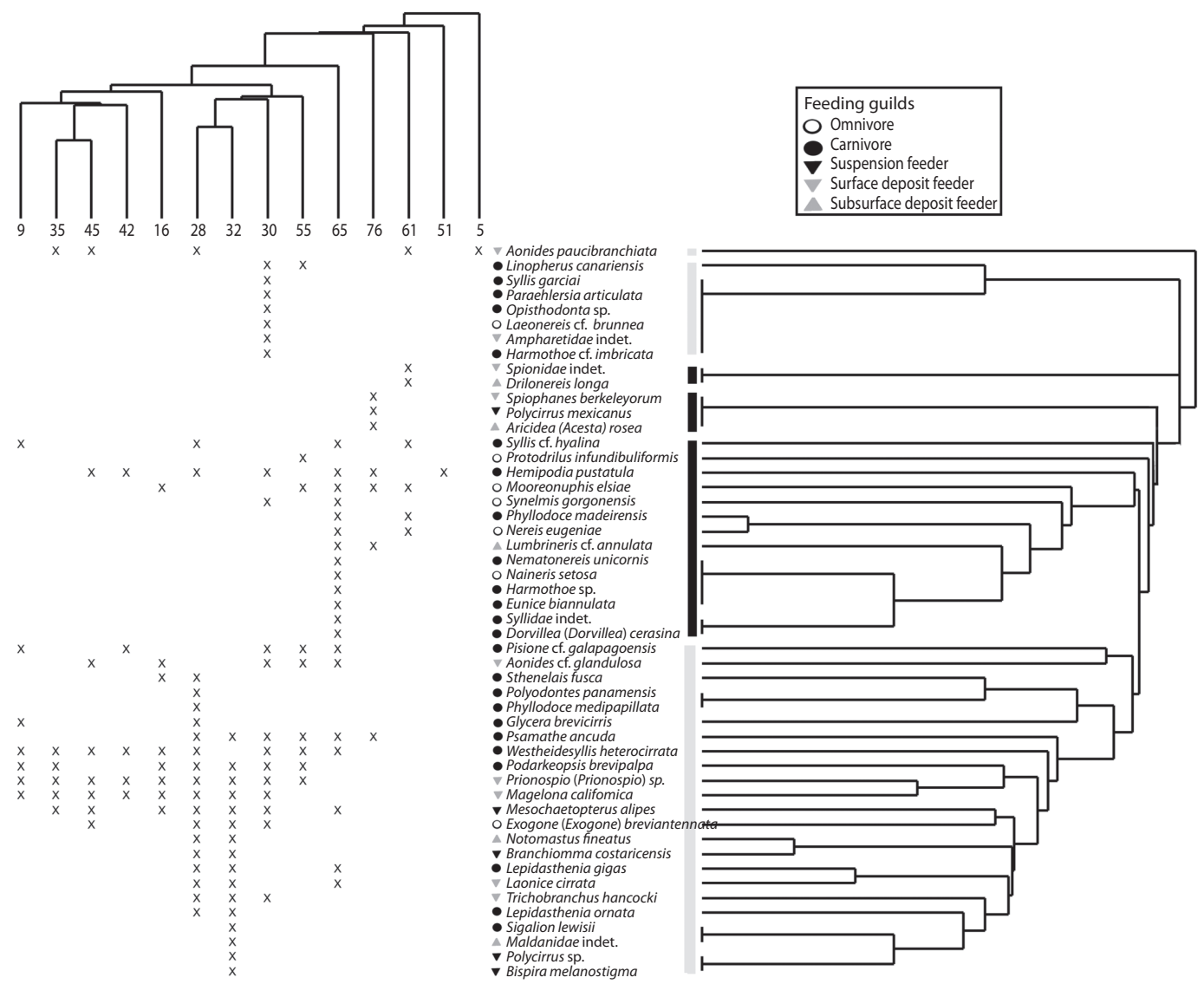

Fig. 2. Cluster analyses (Bray-Curtis, Paired group) for sampling sites (numbers representing depth) and polychaete species based on polychaete abundance data from sandy sediments of Bahía Chatham, Isla del Coco, National Park, Costa Rica. Feeding guilds are presented for each species. Black bars= groups with mainly species of deep stations, Gray bars= groups with mainly species of shallow stations.

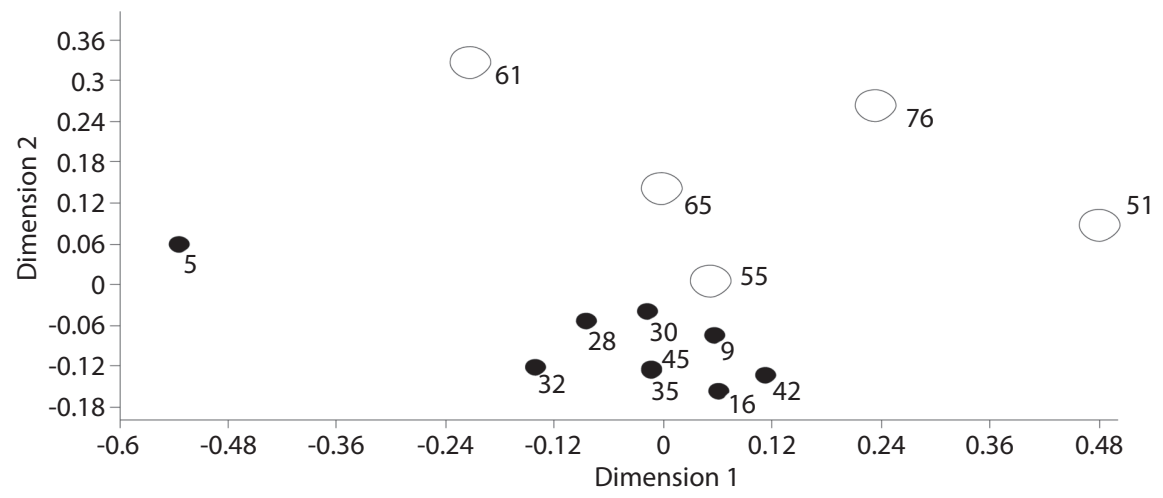

Fig. 3. Non-metric Multidimensional Scaling based on Bray-Curtis similarities among stations (number representing depth) and polychaete abundance data from sandy sediments of Bahía Chatham, Isla del Coco, National Park, Costa Rica. Stress: 0.18 . 
found that were absent from the "deep-water stations" (below 50m) while 14 species were present in "deep-water stations" and absent in "shallow-water stations". The remaining 15 species were present at all depths but were more abundant in the "shallow-water stations".

The most abundant polychaetes in "shallow-water stations" were M. californica, Prionospio (Prionospio) sp. and Mesochaetopterus alipes Monro, 1933. In "deep-water stations", the common taxa were Psamathe ancuda (Wesenberg-Lund, 1962), Pisione cf. galapagoensis Westheide, 1974 and Mooreonuphis elsiae de León-González, 1994. The syllid $W$. heterocirrata was most common in "shallowwater stations" but also was present with high abundance in two "deep-water stations".

\section{DISCUSSION}

In tropical subtidal habitats of Central America, patterns in distribution of benthic communities consist in an increase in diversity or abundance with depth (Maurer \& Vargas 1984, Mair et al. 2009) or decrease due to anoxic conditions in bottom water (LeónMorales \& Vargas 1998). Our data show that polychaetes follow this pattern, but show two peaks at different depth according to multivariate analysis and diversity measures and low value at $51 \mathrm{~m}$ depth. This trend might be explained by the effect of the thermocline in the water column. Thus, the thermocline has been found to occur usually at depths of $50 \mathrm{~m}$ on Cocos Island (Cortés \& Blum 2008). The temperature of the superficial waters was approximate 27 to $29.5^{\circ} \mathrm{C}$ (Acuña-González et al. 2008) and $13^{\circ} \mathrm{C}$ or below in deeper waters (Cortés \& Blum 2008). The abrupt change in temperature was discussed bellow. The fauna also decreased near the shore $(5 \mathrm{~m})$ as in other studies indicated, and possibly causes could be influence of tidal level, fresh water input, increase of temperature (Maurer \& Vargas 1994, Alongi 1990).

The station at $50 \mathrm{~m}$ represented a limit in distribution for some species; decreases in richness and abundance may be related to differences in water stratification. Cortés and Blum (2008) reported that composition of epifauna and demersal fish change rapidly at about $50 \mathrm{~m}$ depth in both sand and rock surfaces of Isla del Coco. Our data, however, were obtained from two sampling trips with the first sampling done only between $28-45 \mathrm{~m}$ while the April 2008 sampling included stations between $5-76 \mathrm{~m}$. For this reason, further sampling is necessary to better understand any temporal differences in the polychaete distribution across depth.

An example of the influence of water condition on the benthic fauna was shown by Reiss et al. (2010) in the North Sea. They found that infaunal abundance is associated with thermal stratification of water, zones with a well-stratified gradient showed lower abundances than those with greater mixing of the water column. Other possible factors controlling the depth range of species are the persistence of the thermocline, the presence of strong currents, and low oxygen conditions near the bottom (Thistle 2003). Additionally, larvae in marine species need certain temperatures for developmental or mitotic processes which could be inhibited at low temperatures (Thistle 2003). Similar factors could influence the benthic polychaete communities of Isla del Coco.

The equitability indicates how the abundance was distributed between the taxa, in the island these values decreased near the shore and around the thermocline depth. In this case the number of species tends to be reduced, but in stations 30 a little decreased was presented. This station was the second in species (19) and individuals (159). The lower equitability is due by the high dominance of $W$. heterocirrata and Exogone (Exogone) breviantennata HartmannSchröder, 1959, and produce a low value in diversity that station 28 .

The species M. californica, Prionospio (Prionospio) sp., and M. alipes are surface deposit or suspension feeders (Fauchald \& Jumars 1979), and are predominant in sand of "shallow-water stations" at Isla de Coco. These stations are closer to the shore and may possibly be enriched by terrestrial input from 
rivers and debris, and by erosion and predation of coral communities (Alongi 1990, Guzmán \& Cortés 1992). Another predominant species was $W$. heterocirrata, a small-sized species that is a possible predator of meiofaunal species (Fauchald \& Jumars 1979).

In the "deep-water stations" carnivorous or mobile species such as $P$. ancuda, $P$. cf. galapagoensis and $M$. elsiae, , were present and were much more abundant than surface or subsurface deposit feeders (Fauchald \& Jumars 1979). The low abundance of deposit feeding species at the "deep-water stations" could be explained by the lower levels of organic matter in tropical carbonate sand shelves in comparison with estuarine systems (Alongi 1989, Maurer \& Vargas 1984). It is possible that at greater depth, the water contains less suspended food due to the oceanic characteristics of the water mass.

This pattern of polychaete feeding guilds is similar to those detected at Las Perlas, Panamá and the Gulf of Nicoya, Costa Rica, sites that also demonstrated a change in functional groups according to sediment characteristics, depth and food availability (Maurer \& Vargas 1984, Mair et al. 2009). The polychaete assemblage in soft sediments on the Costa Rica mainland differs from that in Isla del Coco in presenting a greater presence and diversity of Spionids, Paraonids, Capitellids and Cirratulids (Dean 1996a, b). On the contrary, there were only a few species of Spionids present in soft substrates on Isla del Coco (Dean et al. 2012), whereas Prionospio (Prionospio) sp. was the second most abundant species reported from the island by Dean et al. (2012). The polychaets of México are well studied, and in the Gulf of California for example dominated Spionidae, Onuphidae, Lumbrineridae and Nereididae in subtidal soft bottom (Hernández, 2002), indicant differences between the ecology of these benthic systems.

\section{CONCLUSIONS}

In Isla del Coco, there is a change in diversity and composition of soft-bottom subtidal polychaete species from "shallow to deep waters stations". The effect of the thermocline and/or marked water stratification at the $50 \mathrm{~m}$ isobath could help explain these patterns. The $50 \mathrm{~m}$ depth also represented an apparent limit of distribution in some polychaete species. A peak of diversity and their components at $28-30 \mathrm{~m}$ is possible by low stress environment (e.g. no extreme temperatures). Deposit feeding polychaetes were poorly represented in the sediments of the island possibly due to the low levels of organic matter in the sand sediments of this oceanic island.

This study is exploratory of distribution of polychaete species in Bahía Chatham, future studies are need to investigate whole infaunal community and study spatial patterns around the island. Also seasonal effect is necessary to study in the island.

\section{ACKNOWLEDGMENTS}

Field work for this study was carried out with the help of Eddy Goméz, and the staff of the MV Phoenix and MY Adventure, and CIMAR. The present paper is part of the CIMAR-UCR project "Conocimiento $y$ gestión de medios marinos y coralinos del Área de Conservación Marina Isla del Coco" No. 808-A7-520 of FUNDEVI-UCR, and was funded by the French Fund for the World Environment (FFEM). O. Lizano lent us his petite Ponar grab.

\section{RESUMEN}

El bentos submareal de las islas tropicales ha sido poco estudiado en el Pacífico Oriental. Varios estudios se han publicado sobre colecciones taxonómicas de las islas oceánicas de la región, pero las características ecológicas y la estructura de la comunidad son prácticamente desconocidas. En el presente estudio se muestra la composición de la fauna de anélidos poliquetos según un gradiente de profundidad en los fondos arenosos de la Bahía de Chatham, Parque Nacional Isla del Coco, Costa Rica. Cincuenta especies de poliquetos repartidas en 28 familias fueron encontradas. La comunidad muestra un pico en la diversidad, abundancia y riqueza a los $28-30 \mathrm{~m}$. Los valores fueron menores a $50 \mathrm{~m}$ mientras que por debajo de esta profundidad se observó una tendencia hacia un aumento en 
la riqueza de la comunidad. La composición de las especies cambió de acuerdo a la profundidad y algunas especies sólo se encontraron por debajo o por arriba de los $50 \mathrm{~m}$. La ubicación de la termoclina en la profundidad de $50 \mathrm{~m}$ podría explicar en parte el patrón encontrado.

Palabras clave: Diversidad, Polychaeta, composición, islas oceánicas, infauna, bentos tropical, Isla del Coco, Costa Rica.

\section{REFERENCES}

Acuña-González, J., J. García-Céspedes, E. Gómez-Ramírez, J.A. Vargas-Zamora \& J. Cortés. 2008. Parámetros físico-químicos en aguas costeras de la Isla del Coco, Costa Rica (2001-2007). Rev. Biol. Trop. 56 (Suppl. 2): 49-56.

Aguado, M. \& G. San-Martín. 2006. Sílidos (Syllidae: Polychaeta) del Parque Nacional de Coiba (Pacífico, Panamá). Rev. Biol. Trop. 54: 725-743.

Alongi, D.M. 1989. Ecology of tropical soft-bottom benthos: a review with emphasis on emerging concepts. Rev. Biol. Trop. 37: 85-100.

Alongi, D.M. 1990. The ecology of tropical soft-bottom benthic ecosystems. Oceanogr. Mar. Biol. Ann. Rev. 28: 381-496.

Berkeley, E. \& C. Berkeley. 1939. On a collection of Polychaeta, chiefly from the west coast of Mexico. Ann. Mag. Nat. Hist. 3: 321-346.

Chamberlin, R.V. 1919. The Annelida Polychaeta. Mem. Mus. Comp. Zool. Harvard Coll. 48: 1-514.

Cortés, J. \& S. Blum. 2008. Life to $450 \mathrm{~m}$ depth at Isla del Coco, Costa Rica. Rev. Biol. Trop. 56 (Suppl. 2): 189-206.

de León-González, J.A., J.R. Bastida-Zavala, L.F. Carrera-Parra, M.E. García-Garza, A. Peña-Rivera, S.I. Salazar-Vallejo \& V. Solís-Weiss (Eds.). 2009. Poliquetos (Annelida: Poychaeta) de México y América Tropical. Universidad Autónoma de Nuevo León, Monterrey, México.

Dean, H.K. 1996a. Polychaete worms (Annelida) collected in Golfo Dulce during the Victor Hensen Costa Rica expedition (1993-1994). Rev. Biol. Trop. 44 (Suppl. 3): $81-86$.

Dean, H.K. 1996b. Subtidal benthic polychaetes (Annelida) of the Gulf of Nicoya, Costa Rica. Rev. Biol. Trop. 44 (Suppl. 3): 69-80.

Dean, H.K. 2009. Polychaetes and echiurans. Text: Pp. 181-191, Species List: CD Pp. 122-159. In: I.S. Wehrtmann and J. Cortés (Eds.). Marine Biodiversity of Costa Rica, Central America. Springer + Business Media B.V., Berlin.

Dean, H.K., J.A. Sibaja-Cordero \& J. Cortés. 2012. Polychaetes (Annelida: Polychaeta) of Cocos Island
National Park, Pacific Costa Rica. Pac. Sci. 66: 347-386.

Dexter, D.M. 1974. Sandy beach fauna of the Pacific and Atlantic coast of Costa Rica and Colombia. Rev. Biol. Trop. 22: 51-66.

Fauchald, K. 1977. Polychaetes from intertidal areas in Panama, with a review of previous shallow-water records. Smithsonian Contr. Zool. 221: 1-81.

Fauchald, K. \& P.A. Jumars. 1979. The diet of worms: a study of polychaete feeding guilds. Oceanogr. Mar. Biol. Ann. Rev. 17: 193-284.

Guzmán, H.M. \& J. Cortés. 1992. Cocos Island (Pacific of Costa Rica) coral reefs after the 1982-83 El Niño disturbance. Rev. Biol. Trop. 40: 309-324.

Hammer, Ø., D.A.T. Harper \& P.D. Ryan. 2001. Past, Paleontological Statistics Software Package for Education and Data Analysis. Palaeontol. Elect. 4: 1-9.

Hartman, O. 1959. Catalogue of the polychaetous annelids of the world. Allan Hancock Found. Occ. Paper 23: $1-628$.

Hernández, P. 2002. Composición y estructura de las comunidades de poliquetos (Aannelida: Polychaeta) bénticos de la plataforma continental del Golfo de California. Universidad Nacional Autónoma de México. México.

Hernández-Alcántara, P. \& V. Solís-Weiss. 2011. Distribution of the Polychaete assemblages on the continental shelf of the Northern Gulf of California, Eastern Pacific. Ital. J. Zool. 78 (Suppl. 1): 280-289.

León-Morales, R. \& J.A. Vargas. 1998. Macroinfauna of a tropical fjord-like embayment, Golfo Dulce, Costa Rica. Rev. Biol. Trop. 46 (Suppl. 6): 81-90.

Mair, J.M., S.L. Cunningham, J.A. Sibaja-Cordero, H.M. Guzmán, M.F. Arroyo, D. Merino \& R. Vargas. 2009. Mapping benthic faunal communities in the shallow and deep sediments of Las Perlas Archipelago, Pacific Panama. Mar. Poll. Bull. 58: 375-383.

Maurer, D. \& J.A. Vargas. 1984. Diversity of soft bottom benthos in a tropical estuary, Gulf of Nicoya, Costa Rica. Mar. Bio. 81: 97-106.

Monro, C.G.A. 1928. Polychaeta of the families Polynoidae and Acoetidae from the vicinity of the Panama Canal, collected by Dr. C. Crossland and Dr. Th. Mortensen. J. Linn. Soc. Lond. 36: 553-576.

Nicholds-Driscoll, J. 1976. Benthic invertebrates communities in Golfo Dulce, Costa Rica, an anoxic basin. Rev. Biol. Trop. 24: 281-297.

Quinn, G.P. \& M.J. Keough. 2003. Experimental Design and Data Analysis for Biologists. Cambridge Univ., Cambridge, United Kingdom.

Reiss, H., S. Degraer, G.C.A. Duineveld, I. Kröncke, J. Aldridge, J.A. Craeymeersch, J. D. Eggleton, H. Hillewaert, M. S. S. Lavaleye, A. Moll, T. Pohlmann, 
E. Rachor, M. Robertson, E. Vanden Berghe, G. van Hoey \& H.L. Rees. 2010. Spatial patterns of infauna, epifauna, and demersal fish communities in the North Sea. ICES J. Mar. Sci. 67: 278-293.

Thistle, D. 2003. The deep-sea floor: an overview, Pp. 5-37. In P.A. Tyler (ed.). Ecosystems of the World. 28. Deep Ocean. Elsevier Science, New York.

Treadwell, A.L. 1928. Polychaetous annelids from the Arcturus Oceanographic Expedition. Zoologica 8: 449-485.
Vargas, J.A. 1987. The benthic community of an intertidal mud flat in the Gulf of Nicoya, Costa Rica. Description of the community. Rev. Biol. Trop. 35: 229-316.

Vargas, J.A. 1988. Community structure of macrobenthos and the results of macrodepredator exclusion on a tropical mud flat. Rev. Biol. Trop. 36: 287-308.

Westheide, W. 1974. Interstitielle fauna von Galapagos XI. Pisionidae, Hesionidae, Pilargidae, Syllidae (Polychaeta). Mikrofauna Meeres. 44: 1-146. 
